\title{
Erratum to: microRNA 490-3P enhances the drug-resistance of human ovarian cancer cells

\author{
Shuo Chen ${ }^{1}$, Xi Chen ${ }^{1}$, Yin-Ling Xiu' ${ }^{1}$, Kai-Xuan Sun ${ }^{1}$, Zhi-Hong Zong ${ }^{2}$ and Yang Zhao ${ }^{*}$
}

\section{Erratum}

After publication of [1] it came to the authors' attention that the word "up-regulate" was revised incorrectly into "down-regulate". In Page 1, Abstract and Results section: the last sentence "The mRNA expression levels of MDR1, GST- $\pi . . .$. were down-regulated after miR-490-3P transfection..." should be "...were up-regulated..." In Page 3, Results: the title of the second paragraph was "miR-490-3P down-regulate expression of MDR1/P-gp and GST- $\pi$ ", should be "miR-490-3P up-regulate..." In Page 4, the title of Figure 2 Legend should be "miR-490-3P up-regulate expression of MDR1/P-gp and GST- $\pi$ ".

\section{Author details}

'Department of Gynecology, The First Affiliated Hospital of China Medical University, Shenyang 110001, P.R. China. ${ }^{2}$ Department of Biochemistry and Molecular Biology, College of Basic Medicine, China Medical University,

Shenyang 110001, P.R. China.

Published online: 01 December 2015

\section{Reference}

1. Chen S, Chen X, Xiu Y, Sun K, Zong Z, Zhao Y. microRNA 490-3P enhances the drug-resistance of human ovarian cancer cells. J Ovarian Res. 2014;7:84.

* Correspondence: yida.zhaoyang@163.com

'Department of Gynecology, The First Affiliated Hospital of China Medical University, Shenyang 110001, P.R. China

\section{Submit your next manuscript to BioMed Central} and take full advantage of:

- Convenient online submission

- Thorough peer review

- No space constraints or color figure charges

- Immediate publication on acceptance

- Inclusion in PubMed, CAS, Scopus and Google Scholar

- Research which is freely available for redistribution

Submit your manuscript at www.biomedcentral.com/submit 